\title{
The role of bile and pancreatic juice in the absorption of fat in ewes and lambs
}

\author{
By T. J. HEATH AND BEDE MORRIS \\ Department of Experimental Pathology, John Curtin School of Medical Research, \\ Australian National University, Canberra, A.C.T., Australia
}

(Received 4 December 1962-Revised I March 1963)

In animals with simple stomachs, the dietary triglycerides are largely emulsified and hydrolysed in the lumen of the gut by the action of bile and pancreatic lipase. These processes are important preliminaries to fat absorption, and in dogs and rats deprived of bile or pancreatic juice, fat absorption is significantly reduced (Annegers, 1954).

The role of the lymphatic system in the absorption of fat in sheep and lambs was investigated by Heath \& Morris (1962) and their experiments showed that a considerable proportion of the dietary fat is absorbed into the intestinal lymph and carried to the blood by way of the thoracic duct. In young lambs, the pattern of fat absorption resembles that in cats, rats and rabbits. When a fat meal is given into the rumen of an adult sheep, fat absorption is slow and occurs over a period of days; if, however, the fat meal is given into the abomasum or duodenum, the pattern of absorption is much more rapid.

In sheep under normal conditions, the absorption of fat appears to be a continuous process, and there is evidence that long-chain fatty acids of the dietary lipids are being continuously modified by ruminal micro-organisms. In this regard, it has been shown that the ruminal micro-organisms are capable of hydrolysing long-chain triglycerides (Garton, Hobson \& Lough, I958), and hydrogenating unsaturated fatty acids (Reiser, 195 I; Garton et al. 1958). These preliminary changes which take place in the rumen may be very important in determining the subsequent absorption of the dietary lipids and in modifying the part played by bile and pancreatic juice in the small intestine.

The experiments described in this paper were carried out in vivo to study the effects of continued deprivation of bile and pancreatic juice on the content of lipids in the intestinal lymph and on the lymphatic absorption of ${ }^{14} \mathrm{C}$-labelled fatty acids from the gut of adult sheep and young lambs. Experiments were also done to measure in vitro the lipolytic activity of sheep pancreatic juice in the presence and absence of bile and of calcium ions.

\section{EXPERIMENTAL}

\section{Animals}

Merino ewes and lambs were used for all the experiments. The ewes were between 4 and 6 years of age. They were housed indoors in metabolism cages and fed on lucerne hay and a mixture of lucerne chaff, oaten chaff and grain oats. The lucerne hay and 
lucerne chaff contained per $100 \mathrm{~g}$ dry matter about $3 \mathrm{~g}$ glyceride fat, including $0.8 \%$ phospholipid, and the grain oats contained $7.3 \%$ glyceride fat, including $0.3 \%$ phospholipid. The ewes ingested about $15-30 \mathrm{~g}$ of glycerides each day. Water was always available. The lambs were $2-4$ weeks old and were separated from their mothers. They were bottle-fed on diluted cow's milk with a fat content of about $3 \mathrm{~g} / 100 \mathrm{ml}$.

\section{Surgical procedures}

Intestinal lymph was collected from all the ewes and lambs. Indwelling plastic cannulas (PVC Transflex, Minnesota Mining and Manufacturing Co., Freehold, New Jersey) were placed in the main intestinal lymph duct as described previously (Heath $\&$ Morris, I962). At the same time, fistulas of the common bile duct were established to collect bile or pancreatic juice. Bile was collected from a Transflex cannula (external diameter $2.0 \mathrm{~mm}$ ) placed in the common bile duct just distal to the confluence of the hepatic and cystic ducts. To collect pancreatic juice, a bile fistula was established first and then a second Transflex cannula was placed in the common bile duct $\mathrm{I}-2 \mathrm{~cm}$ before it entered the duodenal wall. All the pancreatic juice drains into the common bile duct in sheep (Taylor, 1960).

Plastic tubes were inserted into the abomasum and duodenum of each ewe, and into the duodenum of each lamb. These tubes were held in place by purse-string sutures.

The lymph, bile and pancreatic juice were collected into plastic containers strapped to the sides of the animals. In some experiments with ewes, bile was returned continuously to the duodenum by means of an infusion pump (Sigmamotor; Middleport, New York). In some experiments with lambs, the bile was returned to the duodenum at hourly intervals through the duodenostomy tube.

In different experiments maize oil, milk or glyceryl tri[ $\left[{ }^{14}{ }^{14} \mathrm{C}\right]$ palmitate was injected into the abomasum or duodenum of the ewes, and glyceryl tri[ $\left[{ }^{-14} \mathrm{C}\right]$ palmitate was injected into the duodenum of the lambs. The labelled tripalmitin was dissolved in olive oil, at the rate of $20 \mu \mathrm{c}$ radioactivity $/ \mathrm{ml}$ oil.

Blood samples were taken from the jugular vein during the experiments. Heparin was used throughout as an anticoagulant.

The faeces passed during the experiments were collected, and at the end of each experiment the animal was destroyed and the intestinal contents were recovered.

\section{Analytical methods}

Chemical and radioactive measurements. Measurements made on samples of lymph and plasma were: (1) total esterified fatty acids by the method of Stern \& Shapiro (1953), (2) free fatty acids by the method of Dole (1956), (3) total cholesterol by the method of Rappaport \& Eichhorn ( 1960$)$, (4) phospholipids by the method of Zilversmit \& Davis (1950), (5) glycerol by the method of Carlson \& Wadström (1959).

Measurements of radioactivity in samples of lymph and plasma were carried out as described previously (Heath \& Morris, 1962 ). The glyceryl tri $\left[\mathrm{I}-{ }^{14} \mathrm{C}\right]$ palmitate used in the experiments was obtained from the Radiochemical Centre, Amersham, Bucks.

Hydrolysis of triglycerides by sheep pancreatic lipase in vitro. To test the effect of bile on the rate of hydrolysis of triglycerides, reaction mixtures containing $0.1 \mathrm{ml}$ 
freshly collected pancreatic juice, $0.5 \mathrm{ml}$ freshly collected sheep bile, $0.5 \mathrm{ml}$ stabilized cottonseed-oil emulsion ( $15 \%$ cottonseed oil in $4 \%$ aqueous dextrose solution, Lipomul IV; The Upjohn Company, Kalamazoo, Michigan), and $10.9 \mathrm{ml}$ Sørensen's phosphate buffer, were incubated at $37^{\circ}$ for periods of up to $2 \mathrm{~h}$. In the control reactions, the bile was replaced by $0.5 \mathrm{ml}$ buffer.

The effect of calcium ions on the rate of hydrolysis of triglycerides was studied by incubating $0.1 \mathrm{ml}$ pancreatic juice with $0.5 \mathrm{ml}$ cottonseed-oil emulsion, $0.5 \mathrm{ml}$ $0.3 \mathrm{M}$-calcium chloride solution, and $10.9 \mathrm{ml} 0.1 \mathrm{M}-N$-ethylmorpholine $(\mathrm{pH} 7.0)$. In control estimations, the calcium chloride solution was replaced by $0.5 \mathrm{ml}$ buffer.

The effect of $\mathrm{pH}$ on the rate of hydrolysis was studied by incubating $\mathrm{I} \cdot 0 \mathrm{ml}$ pancreatic juice with $0.5 \mathrm{ml}$ cottonseed-oil emulsion and Io $\mathrm{ml}$ buffer solutions of varying $\mathrm{pH}$. The buffers used were citrate $(\mathrm{pH} 2 \cdot 2-4 \cdot 2)$, phosphate $\left(\mathrm{pH}_{5} \cdot 4^{-8} \cdot 0\right)$, tris (hydroxy-

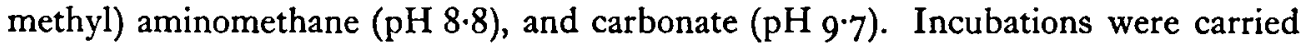
out at $37^{\circ}$ for $30 \mathrm{~min}$.

In each experiment, at the end of the incubation period, the hydrolysis was stopped by the addition of about $O \cdot 1 \mathrm{ml}$ conc. sulphuric acid. The free fatty acids liberated by the hydrolysis were extracted by shaking I $\mathrm{ml}$ of the reaction mixture with $5 \mathrm{ml}$ of a mixture of 40 parts isopropanol, Io parts heptane and I part N-sulphuric acid (Dole, 1956), and the free fatty acids extracted into heptane. The levels of free fatty acids were determined by titration with $0.02 \mathrm{~N}$-sodium hydroxide in a two-phase system using $0.02 \%(\mathrm{w} / \mathrm{v})$ thymol blue in alcohol as indicator. The remaining lipids were extracted from the reaction mixture by washing with diethyl ether, and the diethyl ether was washed with $0.7 \mathrm{M}$-sulphuric acid to remove any glycerol. The sulphuric acid washings were pooled with the reaction mixture, and portions taken for glycerol determination. All estimations were done in duplicate, and control estimations were done at zero time.

\section{RESULTS}

\section{Hydrolysis of triglycerides by sheep pancreatic lipase in vitro}

Fatty acids were liberated rapidly by pancreatic lipase in the absence of bile and calcium ions (Fig. I). However, the percentage of fatty acids liberated during the first 30 min was more than doubled by the addition of bile or calcium ions. Negligible amounts of free glycerol appeared during the first $30-60$ min of incubation, showing that most of the free fatty acids were derived from hydrolysis of triglycerides and diglycerides during this period. Free glycerol appeared subsequently as the reaction proceeded. In samples incubated for $\mathbf{2} \mathrm{h}$, the production of glycerol was increased by the addition of calcium ions but the addition of bile was without effect.

The results of the experiments on the effect of $\mathrm{pH}$ are shown in Fig. 2. The optimum $\mathrm{pH}$ for the hydrolysis of triglycerides in this system was about $7 \cdot 8$. However, appreciable hydrolysis occurred at lower $\mathrm{pH}$ values. Measurements were made of the $\mathrm{pH}$ of the intestinal contents of several sheep and it was found that at a distance of $10 \mathrm{~cm}$ distal to the entrance of the common bile duct, the $\mathrm{pH}$ was 4.2 and the contents of the mid-jejunum had a $\mathrm{pH}$ of $7 \cdot 9$. Hydrolysis occurred in vitro at ranges of $\mathrm{pH}$ between these two values. 
Effect of absence of bile and pancreatic juice on the lipid content of the intestinal lymph

The concentration of total esterified fatty acids, free fatty acids, cholesterol and phospholipids in the intestinal lymph from normal ewes and lambs was always higher than the concentrations of these substances in the plasma. The diversion of bile from the small intestine of ewes produced a rapid decrease in the concentration of total

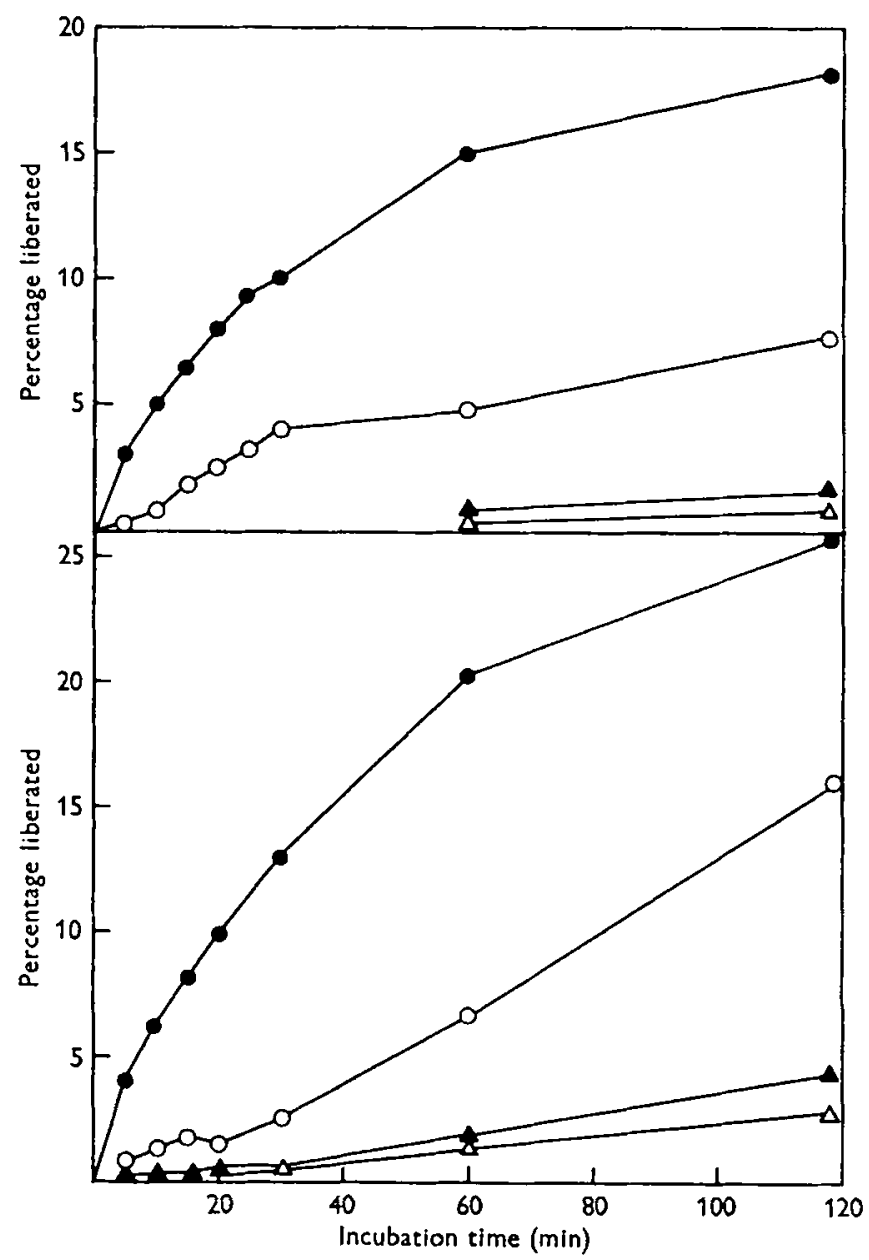

Fig. I. Effect of bile and of calcium ions on the liberation of glycerol and fatty acids by sheep

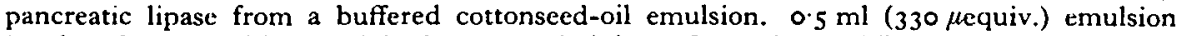
incubated at $37^{\circ}$ with $0.1 \mathrm{ml}$ fresh pancreatic juice. Upper figure: The incubation mixtures were made up to a total volume of $12 \mathrm{ml}$ with Sorensen's phosphate buffer (pH 6.1). and $\Delta-\Delta$, free fatty acids and glycerol respectively in the presence of and, $\multimap \longrightarrow$ and $\Delta-\Delta$, in the absence of $0.5 \mathrm{ml}$ fresh sheep bile. Lower figure: The incubation mixtures were made up to a total volume of $12 \mathrm{ml}$ with $N$-ethylmorpholine $(\mathrm{pH} 700)$. $\bullet$ and $\_-$ free fatty acids and glycerol respectively in the presence of and $0-0$ and $\Delta-\Delta$, in the absence of $0.5 \mathrm{ml} 0.3 \mathrm{M}$-calcium chloride solution.

esterified fatty acids in the intestinal lymph (Fig. 3). Within 6-1o $\mathrm{h}$ the concentrations of total esterified fatty acids, free fatty acids, total cholesterol and phospholipids in the lymph had fallen below the plasma levels. When bile was diverted from the 


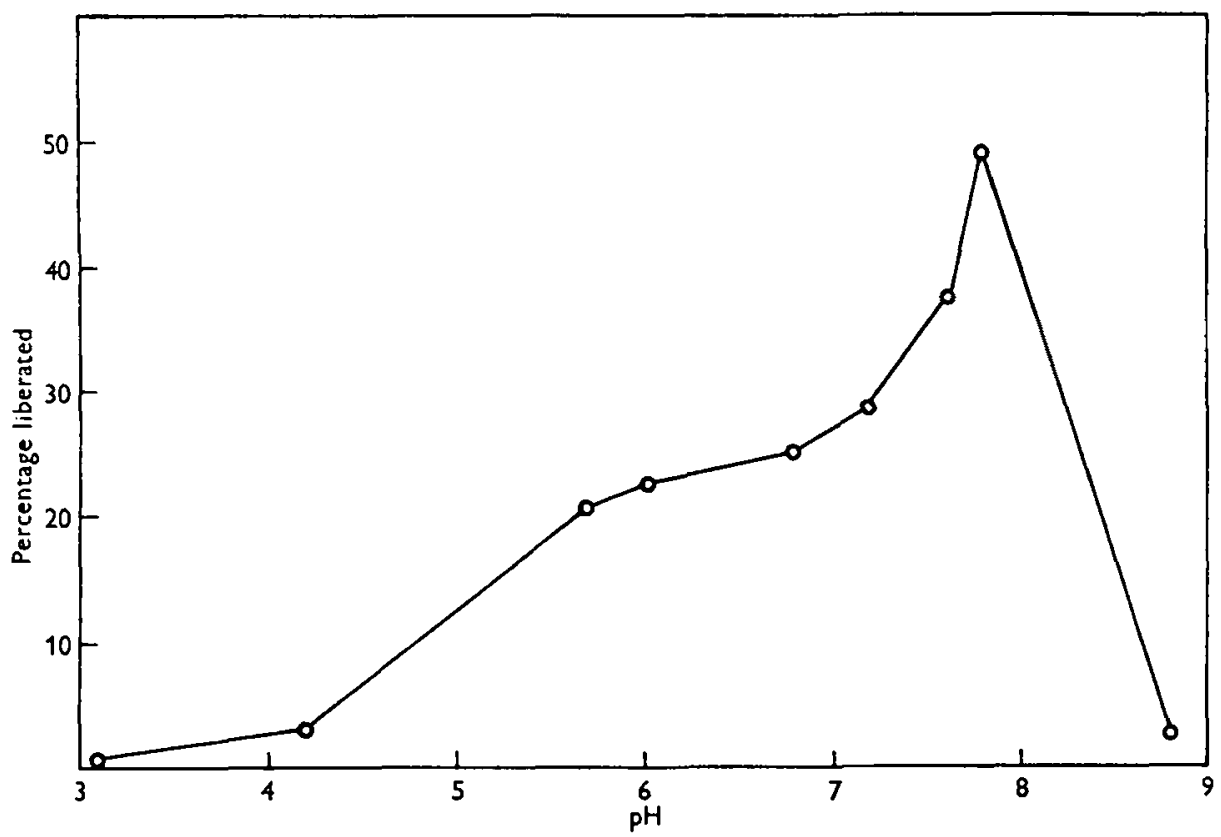

Fig. 2. Effect of $\mathrm{pH}$ on the liberation in vitro of fatty acids from a cottonseed-oil emulsion by sheep pancreatic juice. Fresh pancreatic juice $(\mathrm{r} \cdot 0 \mathrm{ml})$ was incubated for $30 \mathrm{~min}$ at $37^{\circ}$ with $0.5 \mathrm{ml}$ cottonseed-oil emulsion in $10 \mathrm{ml}$ of a buffer solution. Buffers used were citrate (pH 2.2-4.2), phosphate ( $\left.\mathrm{pH}_{5} \cdot 4 \cdot 8 \cdot 0\right)$, tris (hydroxymethyl) aminomethane (pH 8.8) and carbonate $(\mathrm{pH} 9 \cdot 7)$.

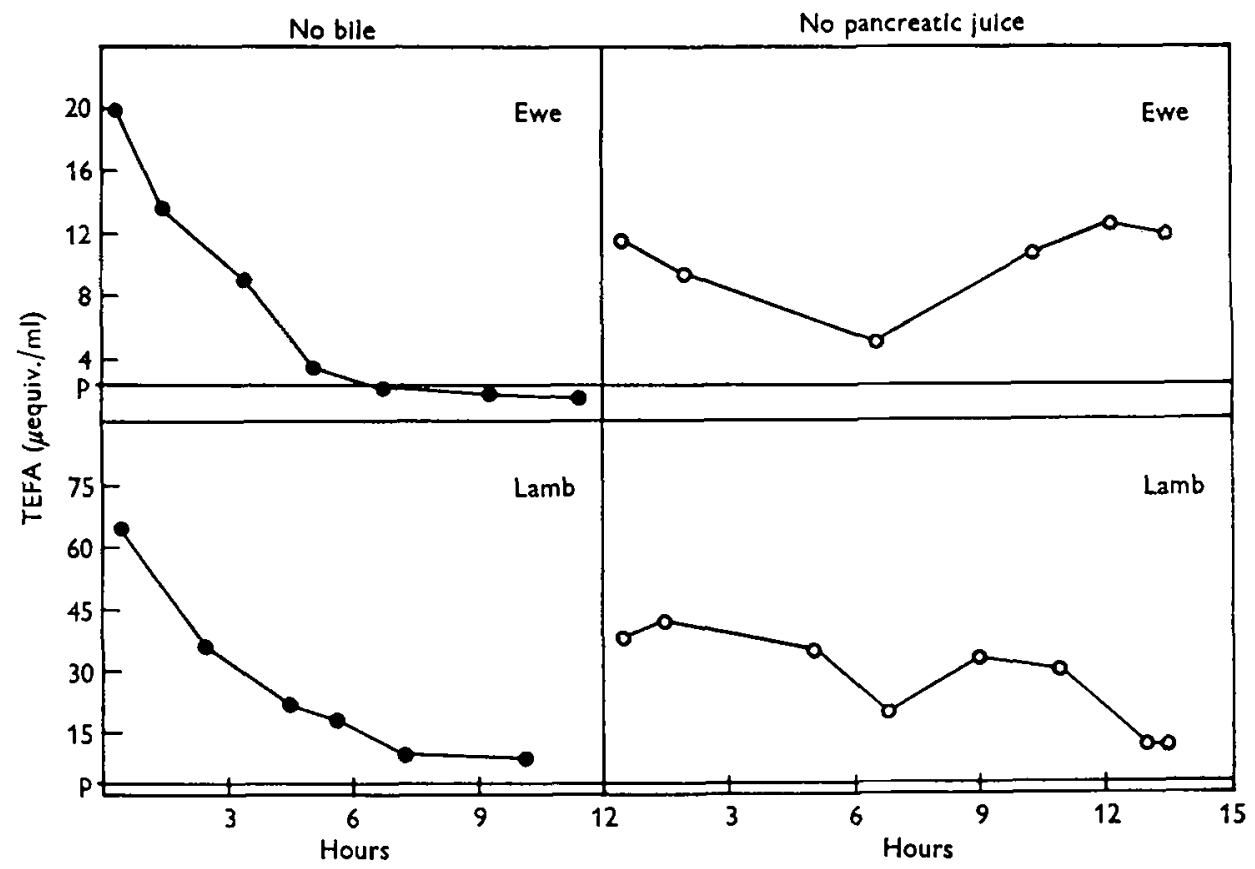

Fig. 3. Concentration of total esterified fatty acids (TEFA) in the intestinal lymph of a ewe and a lamb deprived of bile $(\bullet)$ ) and a ewe and a lamb deprived of pancreatic juice ( $(-0)$. The plasma concentration is shown by the line $p$. 
intestines of lambs, the concentrations of lipids in the intestinal lymph also fell but always remained higher than the plasma concentrations.

The levels of esterified fatty acids in the intestinal lymph of ewes and lambs deprived of pancreatic juice for more than $\mathrm{i} 2 \mathrm{~h}$ were significantly reduced but they remained higher than the levels in the plasma (Tables $I$ and 2). The levels of esterified fatty acids in the lymph fell much more slowly in ewes and lambs deprived of pancreatic juice than in those deprived of bile.

Table I. Concentration of total esterified fatty acids (TEFA) in the intestinal lymph of normal ewes and of eques deprived of bile or pancreatic juice for more than $12 h$

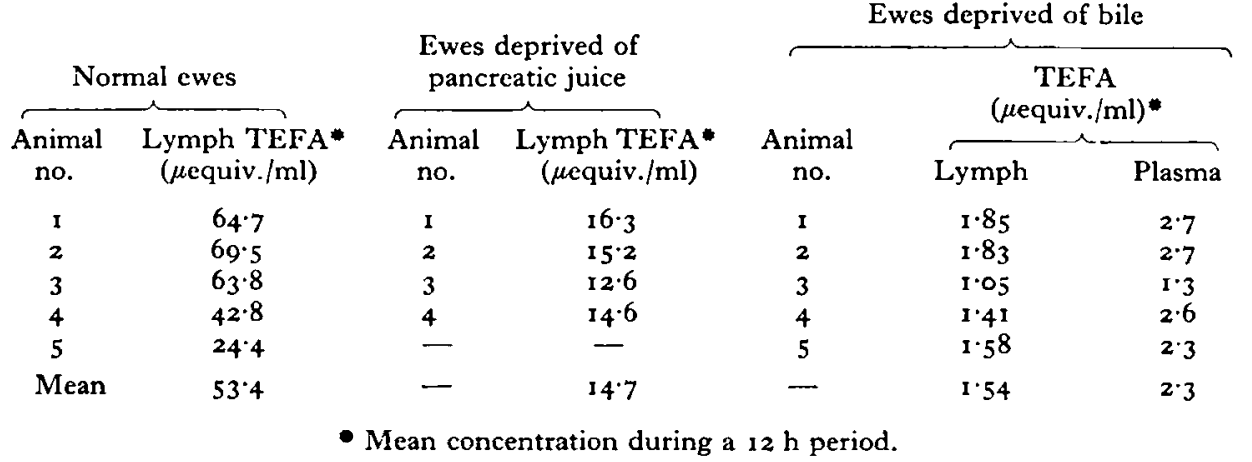

Table 2. Concentration of total esterified fatty acids (TEFA) in the intestinal lymph of normal lambs and of lambs deprived of bile or pancreatic juice or both for more than $12 h$

\begin{tabular}{|c|c|c|c|c|c|c|c|}
\hline \multicolumn{2}{|c|}{ Normal lambs } & \multicolumn{2}{|c|}{$\begin{array}{l}\text { Lambs deprived of } \\
\text { pancreatic juice }\end{array}$} & \multicolumn{2}{|c|}{$\begin{array}{l}\text { Lambs deprived } \\
\text { of bile }\end{array}$} & \multicolumn{2}{|c|}{$\begin{array}{l}\text { Lambs deprived of bile } \\
\text { and pancreatic juice }\end{array}$} \\
\hline $\begin{array}{c}\text { Animal } \\
\text { no. }\end{array}$ & $\begin{array}{c}\text { Lymph } \\
\text { TEFA* } \\
\text { ( } \mu \text { equiv./ml) }\end{array}$ & $\begin{array}{c}\text { Animal } \\
\text { no. }\end{array}$ & $\begin{array}{c}\text { Lymph } \\
\text { TEFA* } \\
\text { ( } \mu \text { equiv./ml) }\end{array}$ & $\begin{array}{c}\text { Animal } \\
\text { no. }\end{array}$ & 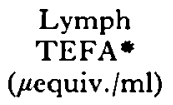 & $\begin{array}{c}\text { Animal } \\
\text { no. }\end{array}$ & 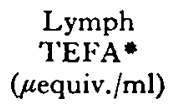 \\
\hline I & $135^{\circ} 0$ & I & $36 \cdot 0$ & $\mathbf{I}$ & $4 \cdot 9$ & 1 & 9.4 \\
\hline 2 & $90 \cdot 6$ & 2 & $13 \cdot 6$ & 2 & $13 \cdot 3$ & 2 & $14 \cdot 6$ \\
\hline 3 & $38 \cdot 3$ & 3 & $27 \cdot 6$ & 3 & $12 \cdot 8$ & 3 & $11 \cdot 7$ \\
\hline 4 & $50 \cdot 0$ & 4 & $22 \cdot 0$ & - & - & 4 & 10.7 \\
\hline 5 & $37 \cdot 9$ & 5 & $44 \cdot 6$ & - & - & - & - \\
\hline Meant & $70 \cdot 3$ & 一 & $28 \cdot 8$ & $\ldots$ & $10 \cdot 3$ & - & $11 \cdot 6$ \\
\hline
\end{tabular}

- Mean concentration during a $12 \mathrm{~h}$ period. The lambs each had a drink of $100-200 \mathrm{ml}$ diluted cow's milk during the collection period.

$\dagger$ Mean plasma TEFA concentration was $4 \cdot 1 \mu$ equiv. $/ \mathrm{ml}$.

\section{Absorption of fat in the absence of bile or pancreatic juice}

The absorption of fat in ewes and lambs is accompanied by characteristic changes in the flow and composition of the intestinal lymph (Heath \& Morris, I 962). When $25 \mathrm{ml}$ maize oil were injected into the abomasum of ewes that had been deprived of bile for more than $12 \mathrm{~h}$, the lymph flow and the concentration of total esterified fatty acids in the lymph did not change. Similarly, injections of $150 \mathrm{ml}$ cow's milk into the duodenum of a ewe deprived of bile did not alter the lymph flow or the concentration of 
esterified fatty acids in the lymph. When lambs deprived of bile were given a drink of milk, there was no consistent change in the lymph flow, but the total esterified fatty acid concentration in the lymph on the average doubled, indicating that some fat absorption was occurring.

In the absence of pancreatic juice, some fat absorption occurred in the presence of bile. When $25 \mathrm{ml}$ maize oil were injected into the abomasum of ewes deprived of pancreatic juice, the total esterified fatty acid concentration in the intestinal lymph increased and reached peaks at 3 and $5^{-7} \mathrm{~h}$, as in normal ewes (cf. Heath \& Morris, 1962). The changes in lymph flow during fat absorption were less well defined than in normal ewes. When lambs deprived of pancreatic juice were given a drink of milk, the lymph flow and total esterified fatty acid concentration increased slightly, but the extent and pattern of the increases were variable.

Table 3. Percentage of tri $\left[{ }^{14} \mathrm{C}\right]$ palmitin (dissolved in olive oil and injected into the abomasum or duodenum) recovered in the intestinal lymph and in the faeces of ewes and lambs deprived of $(A)$ bile or $(B)$ pancreatic juice or $(C)$ both

\begin{tabular}{|c|c|c|c|c|}
\hline Anin & nal no." & Treatment & Lymph & Faeces \\
\hline Lamb & II & A & 5.5 & 84 \\
\hline & 15 & A & 2.5 & \\
\hline & 15 & B & $3.3\}$ & 79 \\
\hline & 16 & B & $2 \cdot 1$ & \\
\hline & 16 & C & $0.42\}$ & 88 \\
\hline & 17 & B & $2.6\}$ & $\mathrm{NC}$ \\
\hline & 17 & C & $10\}$ & \\
\hline & 19 & B & $5.6\}$ & AI \\
\hline & 19 & $\mathrm{C}$ & I.4 $\}$ & 41 \\
\hline Ewe & 16 & A & 0 & 88 \\
\hline & 21 & A & 0 & 100 \\
\hline & 22 & A & 0 & 93 \\
\hline & 24 & A & & 68 \\
\hline & 24 & B & $25\}$ & \\
\hline & 25 & B & $4 \cdot 6$ & NC \\
\hline & 27 & B & $6.8\}$ & $8_{5}$ \\
\hline & 27 & B & $5 \cdot 3\}$ & os \\
\hline
\end{tabular}

NC, not collected.

- Some animals were given two lots tri $\left[{ }^{44} \mathrm{C}\right]$ palmitin under different conditions of bile and pancreatic juice. The recovery of radioactive fat in the lymph is expressed as a percentage of the radioactivity given for each experiment. The recovery of radioactivity in the faeces is expressed as a percentage of the total radioactivity given.

\section{Recovery of $\left[{ }^{14} \mathrm{C}\right]$ tripalmitin given to eqves and lambs deprived of bile or pancreatic juice}

In ewes deprived of bile, no radioactivity appeared in the intestinal lymph after ${ }^{14} \mathrm{C}$-labelled tripalmitin dissolved in olive oil had been injected into the abomasum. Between 80 and $100 \%$ of the radioactivity given was recovered in the faeces. When bile was present but pancreatic juice was absent, an average of $10 \%$ of the radioactive fat was recovered in the lymph (Table 3 ).

In lambs deprived of bile or pancreatic juice, most of the radioactive meal was recovered in the faeces (Table 3 ). If bile was given into the intestine of a lamb 
previously deprived of bile at the same time as the radioactive meal, fat absorption proceeded briskly. The level of radioactivity rose and fell synchronously with the introduction of bile into the intestine (Fig. 4).

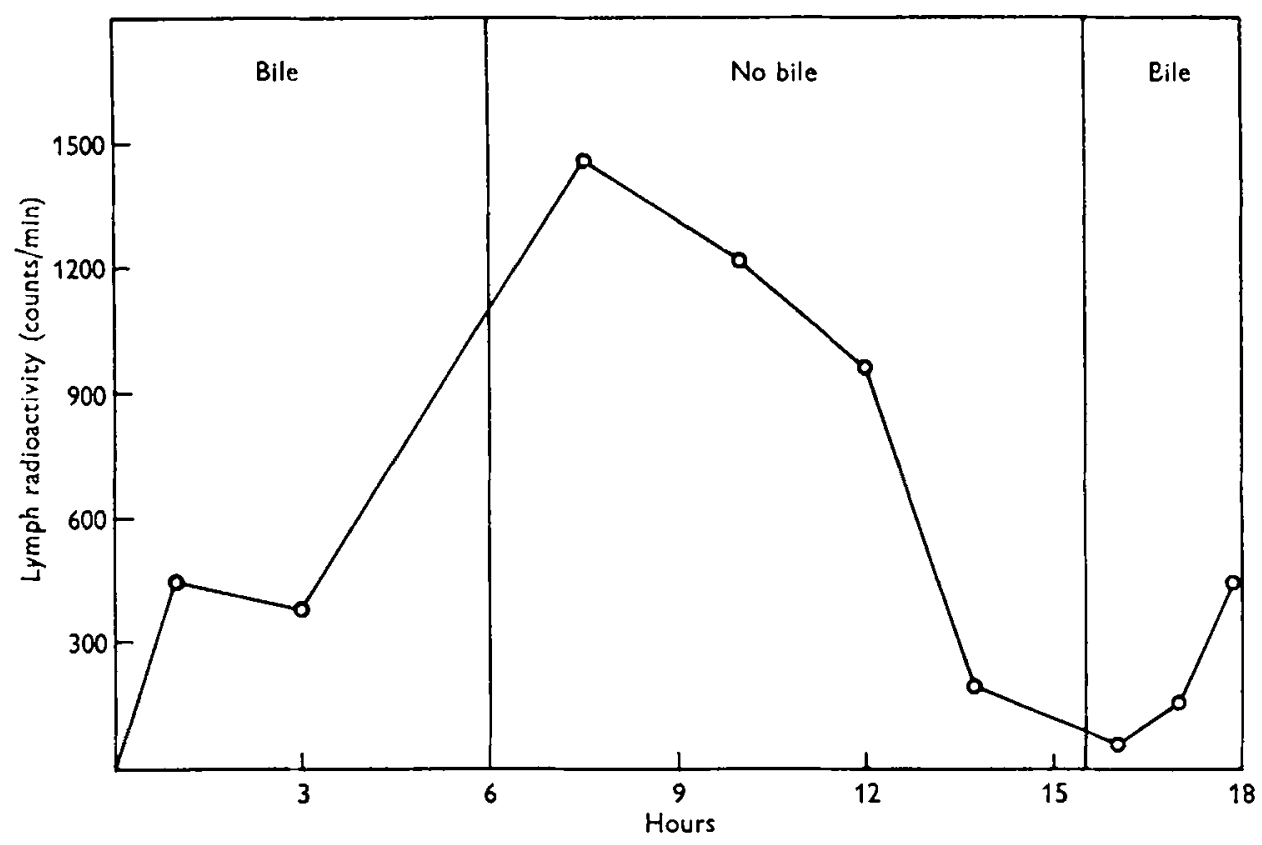

Fig. 4. Effect of bile on the absorption of tri[ $\left.{ }^{14} \mathrm{C}\right]$ palmitin injected into the duodenum of a lamb with a bile-duct fistula. For the first $6 \mathrm{~h}$ bile was returned to the duodenum. Between 6 and $15 \mathrm{~h}$ the bile was diverted from the gut but was returned after $15 \mathrm{~h}$.

\section{DISCUSSION}

It is possible that the effects of bile deprivation on fat absorption might be due to intestinal stasis and a decrease in the rate of movement of material through the gut. There is, however, no evidence that bile deprivation has this effect, and in fact Morgan \& Simmonds (1962) have shown that the rate of stomach emptying is increased in rats deprived of bile. Although no ${ }^{14} \mathrm{C}$-labelled tripalmitin was absorbed in sheep deprived of bile, all the radioactive fat was recovered in the faeces within 2-3 days. Ewes and lambs deprived of bile appeared clinically normal with good ruminal and intestinal movements; they ate well and passed normal amounts of faeces. For these reasons the effects of bile deprivation were thought to be due to impaired absorption from the lumen of the intestine.

Two aspects of the role of bile and pancreatic juice in the absorption of long-chain fatty acids must be considered. The first is related to the function of these secretions in the hydrolysis of the dietary triglycerides and the second is related to their role in converting the dietary fat into a physical form suitable for absorption into the intestinal mucosal cell.

The results of Borgström, Tryding \& Westöo (1957) showed that in man about $40 \%$ of the dietary triglycerides are hydrolysed to glycerol and fatty acids and the remaining 
$60 \%$ are partially hydrolysed. Whereas in the rat and other animals with simple stomachs the hydrolysis of fat is due to the action of pancreatic lipase, in sheep it appears that hydrolysis also occurs in the rumen (Garton et al. 1958). However, when sheep were deprived of pancreatic juice, the concentration of fatty acids in the lymph fell to very low levels, indicating that little dietary fat was being absorbed. If hydrolysis of triglycerides precedes fat absorption, and this is the main function of pancreatic lipase, it would seem that the absorption of dietary long-chain triglycerides from the small intestine is not influenced to any extent by lipolysis occurring in the rumen.

Pancreatic juice of ewes and lambs appears to have an activity towards long-chain fatty acid esters similar to that of the pancreatic juice of the rat, pig and man. Although the optimum $\mathrm{pH}$ for the hydrolysis of triglycerides in the system used was about $7 \cdot 8$, appreciable hydrolysis occurred at lower $\mathrm{pH}$ values. The observation of Borgström (1954) that the presence of bile salts depresses the optimum $\mathrm{pH}$ for the hydrolysis of triglycerides by rat pancreatic lipase suggests that the contents of the upper part of the sheep's small intestine provide appropriate conditions for the hydrolysis of triglycerides. The results of in vitro experiments showed that bile increased the hydrolysis of triglycerides to free fatty acids and partial glycerides by pancreatic lipase. These water-insoluble products have been shown to enter micelles formed by bile salts in the intestinal lumen (Hofman \& Borgström, 1962). These authors suggest that fat is absorbed from the gut in this form.

\section{SUMMARY}

I. The role of bile and pancreatic juice in the absorption of fat in ewes and lambs has been investigated. Chronic fistulas of the bile and pancreatic ducts were established in ewes and lambs and the absorption of chaff lipids, maize oil and tri[ $\left[{ }^{14} \mathrm{C}\right]$ palmitin into the intestinal lymph was studied. Factors affecting the hydrolysis of triglycerides by sheep pancreatic lipase have also been studied in in vitro experiments.

2. In vitro, the optimum $\mathrm{pH}$ for the hydrolysis of triglycerides of long-chain fatty acids by sheep pancreatic lipase was about $7 \cdot 8$. Appreciable hydrolysis occurred over the range of $\mathrm{pH}$ values found in the small intestine of sheep. The liberation of free fatty acids from triglycerides by sheep pancreatic juice in vitro was increased in the presence of calcium ions and bile.

3. When sheep were deprived of bile, the concentrations of lipid in the intestinal lymph fell rapidly and within $\mathrm{Io} h$ were less than the plasma concentrations. The content of lipid in the intestinal lymph of lambs deprived of bile also decreased but remained higher than in the plasma. In sheep and lambs deprived of pancreatic juice, the content of lipid in the intestinal lymph was much lower than in normal sheep and lambs.

4. The absorption of maize oil and also of tri[ $\left[-{ }^{14} \mathrm{C}\right]$ palmitin was reduced in sheep and lambs deprived of pancreatic juice and in lambs deprived of bile. No $\operatorname{tri}\left[\mathrm{r}^{14} \mathrm{C}\right]-$ palmitin was absorbed in sheep deprived of bile.

We should like to thank Mrs H. Kobau for her technical assistance. 


\section{REFERENCES}

Annegers, J. H. (1954). Arch. intern. Med. 93, 9.

Borgström, B. (1954). Biochim. biophys. Acta, 13, 149.

Borgström, B., Tryding, N. \& Westöö, G. (1957). Acta physiol. scand. 40, 241.

Carlson, L. A. \& Wadström, L. B. (1959). Clin. chim. acta, 4, I 97.

Dole, V. P. (1956). Y. clin. Invest. 35, 150.

Garton, G. A., Hobson, P. N. \& Lough, A. K. (1958). Nature, Lond., 182, 15 I I.

Heath, T. J. \& Morris, B. (1962). Quart. 7. exp. Physiol. 47, 157.

Hofmann, A. F. \& Borgström, B. (1962). Fed. Proc. 21, 43.

Morgan, R. G. H. \& Simmonds, W. J. (1962). Quart. F. exp. Physiol. 47, 352.

Rappaport, F. \& Eichhorn, F. (1960). Clin. chim. acta, 5, 16r.

Reiser, R. (1951). Fed. Proc. ro, 236.

Stern, I. \& Shapiro, B. (1953). F. clin. Path. 6, 158.

Taylor, R. B. (1960). Res. vet. Sci. I, II I.

Zilversmit, D. B. \& Davis, A. K. (1950). Y. Lab. clin. Med. 35, I 55. 